\title{
Chemoprevention with green propolis green propolis extracted in $L$ - lysine versus carcinogenesis promotion with $L$-lysine in N-Butyl-N-[4-hydroxybutyl] nitrosamine (BBN) induced rat bladder cancer ${ }^{1}$
}

\author{
Quimioprevenção com própolis verde extraído em L-Lisina versus promoção da carcinogênese \\ como $L$ - Lisina em ratos induzidos ao câncer de bexiga pelo N-Butyl-N-[4-hydroxybutyl] \\ nitrosamine $(\mathrm{BBN})$
}

\begin{abstract}
Conceição Aparecida Dornelas ${ }^{\mathrm{I}}$, Francisco Vagnaldo Fechine-Jamacaru ${ }^{\mathrm{II}}$, Irineu Lima Albuquerque ${ }^{\mathrm{III}}$, Hemerson Iury Ferreira Magalhães $^{\text {IV }}$, Adjair Jairo Silva de Souza ${ }^{\text {, }}$ Leonardo Alcântara Alves ${ }^{\text {VI }}$, Paulo Roberto Carvalho de Almeida ${ }^{\text {VII }}$, Telma Leda
\end{abstract} Gomes de Lemos $^{\mathrm{VIII}}$, José Daniel Vieira de Castro ${ }^{\mathrm{IX}}$, Maria Elisabete Amaral Moraes ${ }^{\mathrm{X}}$, Manoel Odorico Moraes ${ }^{\mathrm{XI}}$

${ }^{\mathrm{I}} \mathrm{PhD}$, Associate Professor, Department of Pathology, UFC, Ceara, Brazil. Responsible for conception of the scientific content, delineation of the project, execution of the study and manuscript writing. This paper is part of doctorate thesis, Postgraduate Program, Department of Surgery, UFC, Brazil.

IIPhD, Visiting Professor, Department of Physiology and Pharmacology, UFC, Ceara, Brazil. Responsible for the interpretation of the data and statistical analysis.

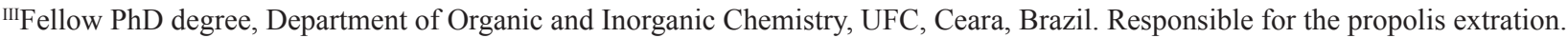

${ }^{\text {IV }} \mathrm{PhD}$, Fellow Post PhD degree, Department of Physiology and Pharmacology, UFC, Ceara, Brazil. Responsible guidance and monitoring in weighing and dilution of the products used in the experiment.

${ }^{\mathrm{V}}$ Graduate student, Department of Physiology and Pharmacology, UFC, Ceara, Brazil. Animal care and treatment.

${ }^{\mathrm{VI}}$ Graduate student, Department of Organic and Inorganic Chemistry, UFC, Ceara, Brazil. Helped propolis extraction and lyophilization.

${ }^{\mathrm{VII}} \mathrm{PhD}$, Associate Professor, Department of Pathology, UFC, Ceara, Brazil. Histological analyses.

VIIIPhD, Associate Professor, Department of Organic and Inorganic Chemistry, UFC, Ceara, Brazil. Supervision throughout the procedure to extract the propolis.

${ }^{\mathrm{IX}}$ Associate Professor, Department of Radiology, UFC, Ceara, Brazil. Responsible for the ultrasound images.

${ }^{x}$ Associate Professor, Department of Physiology and Pharmacology, UFC, Ceara, Brazil. Critical revision.

${ }^{\mathrm{xI}}$ Chairman, Department of Physiology and Pharmacology, UFC, Ceara, Brazil. Supervision of all phases of the study. Tutor of the doctorate thesis.

\section{ABSTRACT}

PURPOSE: To determine the effects of green propolis extracted in $L$ - lysine (WSDP) and of $L$ - lysine for 40 weeks on induced rat bladder carcinogenesis.

METHODS: The animals (groups I, II, III, IV, V and VI) received BBN during 14 weeks. Group I was treated with propolis 30 days prior received BBN, and then these animals were treated daily with propolis; Groups II and III was treated with subcutaneous and oral propolis (respectively) concurrently with BBN. The animals of Group IV were treated $L$-lysine; Group V received water subcutaneous; and Group VI received only to BBN. Among the animals not submitted to carcinogenesis induction, Group VII received propolis, Group VIII received $L$-lysine and Group IX received water.

RESULTS: The carcinoma incidence in Group I was lower than that of control (Group VI). The carcinoma multiplicity in Group IV was greater than in Group VI. All animals treated with $L$-lysine developed carcinomas, and they were also more invasive in Group IV than in controls. On the other hand, Group VIII showed no bladder lesions.

CONCLUSION: The WSDP is chemopreventive against rat bladder carcinogenesis, if administered 30 days prior to BBN , and that $L$-lysine causes promotion of bladder carcinogenesis.

Key words: Lysine. Propolis. Urogenital Neoplasms. Rats.

\section{RESUMO}

OBJETIVO: Determinar os efeitos da própolis verde extraída em $L$ - Lisina (WSDP) e da $L$ - Lisina por 40 semanas em ratos induzidos 
a carcinogênese de bexiga.

MÉTODOS: Os animais (grupos I, II, III, IV, V e VI) receberam BBN por 14 semanas. O grupo I foi tratado com própolis 30 dias antes de receber BBN e em seguida estes animais foram tratados diariamente com própolis; Os grupos II e III foram tratados com própolis subcutânea e oral (respectivamente) e concorretemente com BBN. Os animais do grupo IV foram tratados com $L$ - Lisina; o grupo V recebeu água subcutânea; o grupo VI recebeu apenas BBN. Entre os animais não submetidos a indução de carcinogênese, Grupo VII, receberam própolis Grupo VIII, receberam $L$ - Lisina e Grupo IX receberam água.

RESULTADOS: A incidência de carcinoma no grupo I foi menor que no grupo controle (grupo IV) A multiplicidade de carcinoma no grupo IV foi maior que no grupo VI. Todos os animais tratados $\operatorname{com} L$ - Lisina desenvolveram carcinomas e estes foram mais invasivos no grupo IV que no grupo controle. Por outro lado o grupo VIII não apresentou lesões.

CONCLUSÃO: WSDP é quimiopreventiva contra a carcinogese de bexiga se administrada 30 dias antes do início do BBN, e a $L$ - Lisina causa promoção da carcinogênese de bexiga

Descritores: Lisina. Própole. Neoplasias Urogenitais. Ratos.

\section{Introduction}

Bladder cancer is a highly prevalent disease, especially in North European countries such as Scotland and Denmark ${ }^{1}$. In the US, the incidence increased by $50 \%$ among men and by $25 \%$ among women between 1985 and 2006. This does not appear to be due to technological advances in diagnostic techniques, since bladder cancer is rarely discovered incidentally ${ }^{2}$. In 2011, an estimated 69,250 new cases and 14,990 deaths from bladder cancer are expected to occur in the US alone ${ }^{3}$. Bladder cancer is associated with direct exposure to industrial chemicals, water contamination by arsenic, smoking, radioactivity (such as from the nuclear bombs in Japan and the disaster in Chernobyl, Ukraine), abuse of analgesics (such as phenacetin) and vesical schistosomiasis (common in parts of Africa and the Middle East) ${ }^{1}$

N-Butyl-N-[4-hydroxybutyl] nitrosamine $(\mathrm{BBN})$ is a direct and indirect carcinogen capable of initiating and promoting carcinogenesis and is site-specific to the urinary epithelium. In rats, tumors are multifocal, superficial and dose-dependent, and BBN progressively induces hyperplasia, papilloma and carcinoma in transitional cells. The mouse model is characterized by carcinoma in situ with early invasion of the bladder wall ${ }^{4,5}$.

Propolis is a resinous substance that honey bees collect from botanical sources and mix with their own saliva. It helps maintain aseptic conditions and appropriate temperature in the hive. The diversity of plants in the vicinity of the hive is the main factor determining the chemical composition of propolis ${ }^{6,7}$.

Green propolis, so called because of the presence of green pigment from the native shrub species Baccharis dracunculifolia $^{6}$, is a Brazilian variety of propolis known for its many pharmacological properties. Among the most promising is the anticarcinogenic action of its constituents, some of which have been tested in laboratory animals and human cell culture ${ }^{8-10}$.
However, insolubility in water makes propolis compounds difficult to test in laboratory models in vivo. To overcome this difficulty, Bulgarian researchers developed a method for extracting a water-soluble derivative of propolis (WSDP) using a solution containing $8 \%$-lysine $\square$ an essential amino acid ${ }^{11}$.

While some amino acids are known to promote bladder carcinogenesis $^{12-14}$ through enhancing the proliferation of initiated cells and induction of additional mutations, such effects have not been reported for $L$-lysine (The objective of this study was to evaluate the effect of long-term administration of WSDP on $\mathrm{BBN}$-induced rat bladder cancer in vivo over a period of 14 weeks, including an evaluation of the effects of $L$-lysine on controls.

\section{Methods}

Water-soluble derivative of propolis (WSDP): Green propolis was collected in Minas Gerais (Brazil) in September and October. A water-soluble extract was prepared at the Department of Organic and Inorganic Chemistry (Federal University of Ceara) following patented procedure ${ }^{11}$ with slight modifications. Propolis was extracted in ethyl alcohol, submitted to liquidliquid partitioning with ether and concentrated in a warm water bath. WSDP was prepared with $100 \mathrm{~g}$ propolis in $1500 \mathrm{~mL}$ of $8 \%$ $L$-lysine, heated to $51-60^{\circ} \mathrm{C}$, lyophilized and cold-stored in small sterilized vials appropriate for the administration of $150 \mathrm{mg} /$ $\mathrm{kg}$ body weight. A sample of lyophilized propolis $(40.41 \mathrm{mg} / \mathrm{g})$ was submitted to high-performance liquid chromatography for chemical characterization, and was found to contain $0.385 \mathrm{mg} / \mathrm{g}$ (0.04\%) 3-[4-hydroxyl-3 (oxo-butenyl) phenyl acrylic] acid (derivate 1, UV spectrum identical to that of artepillin C), 0.453 $\mathrm{mg} / \mathrm{g}(0.04 \%)$ 3-prenyl-4-hydroxycinnamic acid, $2.450 \mathrm{mg} / \mathrm{g}$ $(0.24 \%)$ caffeic acid, $1.128 \mathrm{mg} / \mathrm{g}(0.11 \%)$ caffeoylquinic acid, and $35.99 \mathrm{mg} / \mathrm{g}(3.60 \%) \mathrm{p}$-coumaric acid. 
The study used 77 five-week-old female Wistar rats accommodated in polyethylene cages ( 5 per cage) at $22^{\circ} \mathrm{C}$ with a 12/12-hour circadian cycle. The animals had access to food (Biobase ${ }^{\circledR}$ pelleted ration) and water ad libitum.

The laboratory animal facility and the handling of animals and materials followed WHO safety guidelines ${ }^{15,16}$.

\section{$N$-Butyl-N-[4-hydroxybutyl] nitrosamine (BBN)}

BBN was purchased from TCI America (9211 N. Harborgate Street, Portland, OR 97203; CAS \#3817-11-6) and stored at $4{ }^{\circ} \mathrm{C}$. Each vial containing $97 \%$ BBN was diluted to $2.5 \%$ in mother solution and rediluted to $0.05 \%$ in potable water every other day for 14 weeks.

\section{L-Lysine}

The amino acid L-lysine monohydrochloride $\left(\mathrm{C}_{6} \mathrm{H}_{14} \mathrm{~N}_{2} \mathrm{O}_{2} \cdot \mathrm{HCl}\right.$; CAS \#657-27-2) was prepared for extraction as a distilled water solution at $8 \%$ and administered in doses of 150 $\mathrm{mg} / \mathrm{kg}$.

\section{Experimental procedures}

The study was previously approved by the UFC Ethics Committee for Animal Research under protocol \#03/06 and was carried out in accordance with the guidelines of the Brazilian College of Animal Testing. Figure 1 shows the design of the experiment:

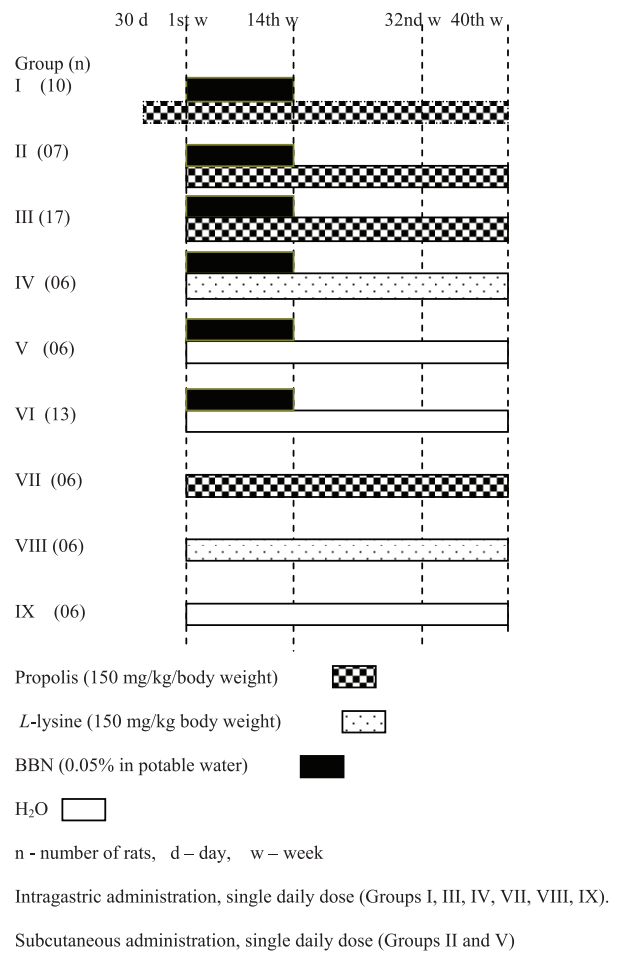

FIGURE 1 - Design of the experiment.

\section{Ultrasound scanning}

At 31 and 40 weeks all animals were anesthetized peritoneally with $80 \mathrm{mg} / \mathrm{kg}$ ketamine and $8 \mathrm{mg} / \mathrm{kg}$ xylazine and submitted to ultrasound scanning of the bladder in horizontal and sagittal sections using a 12-MHz linear transducer (Philips).

Mapping and histopathological evaluation of vesical lesions

The rats were euthanized with an overdose of anesthetics and submitted to necropsy for evaluation of the abdominal and thoracic organs. After urethra and bilateral ureter ligature, the bladder was filled with $10 \%$ formaldehyde, opened in coronal section (antero-posteriorly) and photographed. The lesions were mapped, identified and cut along the greatest diameter to obtain samples for histological analysis with hematoxylin-eosin staining. The histopathological study followed the guidelines of the International Agency for Research on Cancer and the World Health Organization ${ }^{4,5}$.

\section{Statistical analysis}

Quantitative variables, both continuous and discrete, were initially analyzed with the Kolmogorov-Smirnov test to determine normality of distribution. Nominal qualitative variables were expressed as relative or absolute frequencies and analyzed with the chi-square test or Fisher's exact test, while ordinal qualitative variables were expressed as means, interquartile ranges and minimum and maximum values and analyzed with the MannWhitney $U$ test. In all cases, the level of statistical significance was set at $p<0.05$. Analyses were performed with the help of GraphPad v. 5.00 for Windows ${ }^{\circledR}$ (GraphPad Software, San Diego, California, USA, 2007).

\section{Results}

By the 40th week, $100 \%$ of the animals receiving BBN showed intravesical lesions. All lesions were multifocal (focal or diffuse), papillary, polypoid, delicate, pinkish, cauliflower-like and either sessile or pedunculated. Some of the larger lesions displayed areas of necrosis and bleeding while invading the wall, adjacent tissues and local lymph nodes (Figures 2, 3 and 4). 


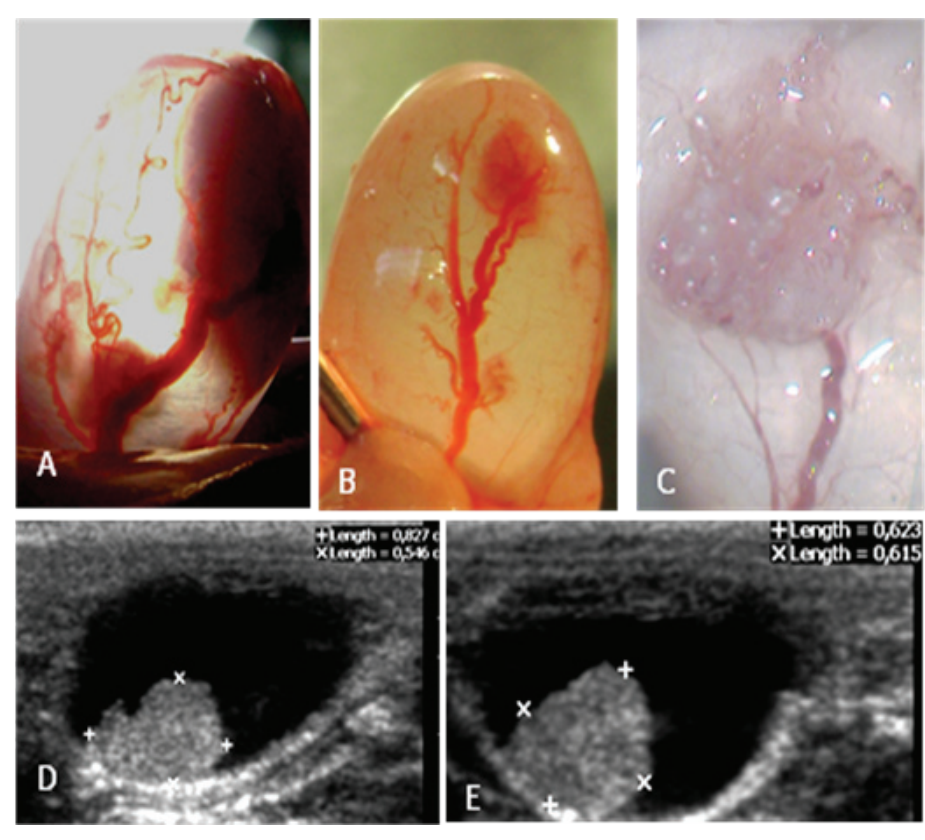

FIGURE 2 - (A and B) Transilluminated bladders of anesthetized rats with sinuous vessels entering tumor shadow; $(\mathbf{C})$ Bladder in $10 \%$ formaldehyde solution displaying cauliflower-like lesion 40x; (D e E) Ultrasound scan showing tumor projecting from bladder wall.

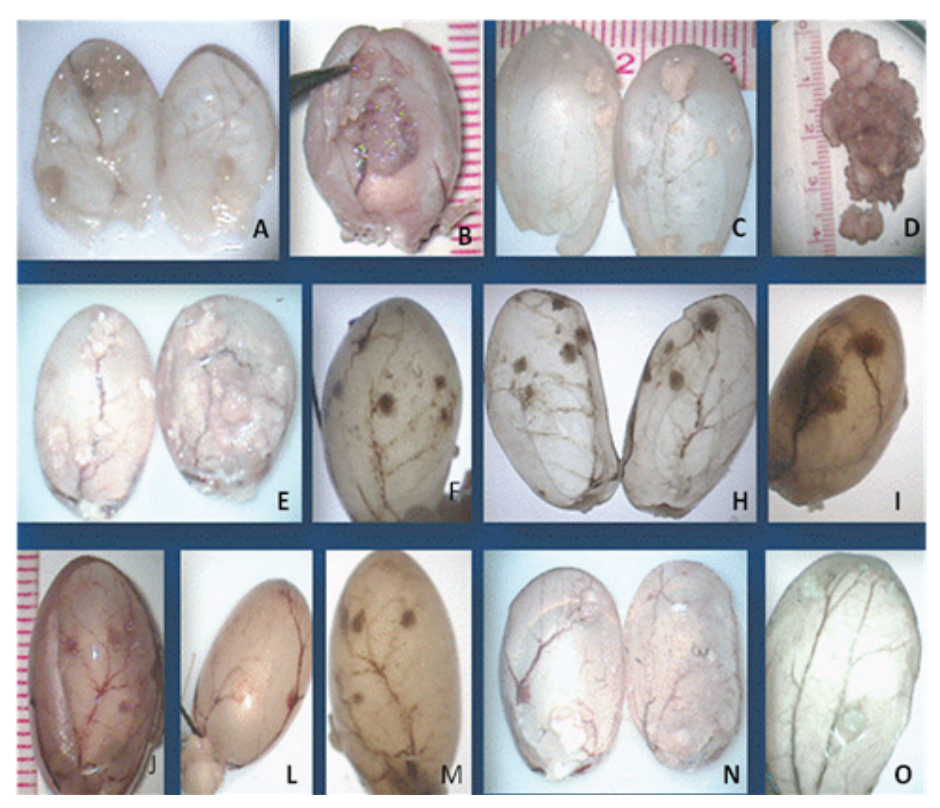

FIGURE 3 - (A-O) Group I, bladder tumors; 3B and 3D, bladder carcinomas.

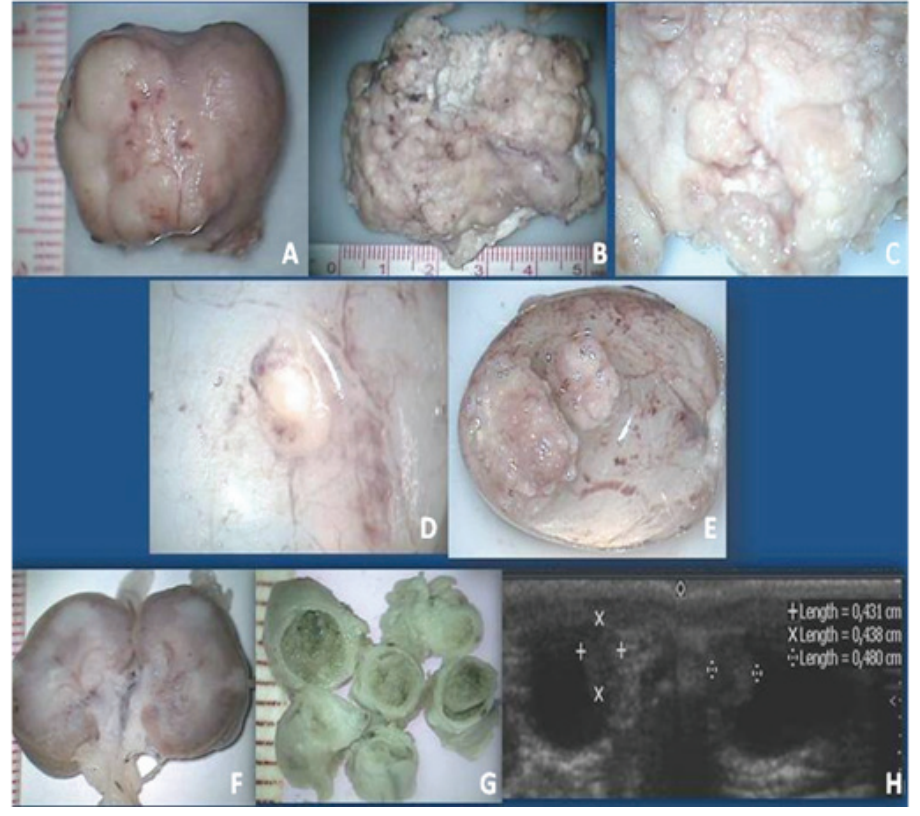

FIGURE 4 - (A, B, C, D and E) Bladder carcinomas (Group IV, rats 1,2,3,4 and 5); 4 (F, G), and $4 \mathrm{H}$ kidney, ureter carcinoma and ultrasound scan ( $31^{\mathrm{a}}$ week) bladder tumor (Group IV, rat 6: This animal was excluded from the study because the bladder has been lost).

Table 1 shows the incidence of benign, premalignant and malignant changes detected in the histopathological study. 
TABLE 1 - Carcinogenesis in rat bladder: incidence of hyperplasias (flat, papillary, nodular), papillomas, lesions of low malignant potential and carcinomas.

\begin{tabular}{|c|c|c|c|c|c|c|c|c|c|c|c|c|c|}
\hline \multirow{3}{*}{$\begin{array}{c}\text { G } \\
\text { I }\end{array}$} & \multirow{3}{*}{$\begin{array}{c}\mathbf{N}^{\circ} \\
10\end{array}$} & \multicolumn{12}{|c|}{ Histopathology Incidence (number and percentage of rats) } \\
\hline & & \multicolumn{2}{|c|}{ FLH } & \multicolumn{2}{|c|}{ PPH } & \multicolumn{2}{|c|}{ NDH } & \multicolumn{2}{|c|}{ PAP } & \multicolumn{2}{|c|}{ LLMP } & \multicolumn{2}{|c|}{ CARCINOMA } \\
\hline & & 8 & 80.00 & 9 & 90.00 & 2 & 20.00 & 9 & 90.00 & 6 & 60.00 & 2 & $20.00^{\mathrm{b}}$ \\
\hline II & 7 & 5 & 71.42 & 5 & 71.42 & 2 & 28.57 & 5 & 71.42 & 4 & 57.14 & 2 & $28.57^{\mathrm{a}}$ \\
\hline III & 17 & 15 & 88.23 & 15 & 88.23 & 7 & 41.17 & 16 & 94.11 & 13 & 74.47 & 11 & $64.70^{\mathrm{c}}$ \\
\hline IV & 5 & 4 & 80.00 & 3 & 60.00 & 2 & 40.00 & 3 & 60.00 & 3 & 60.00 & 5 & 100.00 \\
\hline V & 6 & 6 & 100.00 & 5 & 83.33 & 0 & 00.00 & 4 & 66.66 & 0 & 00.00 & 1 & 16.66 \\
\hline VI & 12 & 10 & 83.33 & 10 & 83.33 & 5 & 41.66 & 9 & 75.00 & 3 & 25.00 & 8 & 66.66 \\
\hline VII & 6 & 0 & 0 & 0 & 0 & 0 & 0 & 0 & 0 & 0 & 0 & 0 & 0 \\
\hline VIII & 6 & 0 & 0 & 0 & 0 & 0 & 0 & 0 & 0 & 0 & 0 & 0 & 0 \\
\hline IX & 6 & 0 & 0 & 0 & 0 & 0 & 0 & 0 & 0 & 0 & 0 & 0 & 0 \\
\hline
\end{tabular}

$\mathrm{G}$ - groups; $\mathrm{N}^{\circ}$ - number of rats ; FLH - flat hyperplasia; PPH - papillary hyperplasia; NDH - nodular hyperplasia;

LLMP - lesions of low malignant potential; PAP - papilloma

a different from Group IV: $p=0.0278$ (Fisher's exact test)

b different from Group VI: $p=0.0427$ (Fisher's exact test)

${ }^{c}$ different from Group I: $p=0.0461$ (Fisher's exact test)

Table 2 shows carcinoma multiplicity (number of carcinomas per animal) in each group in relation to tumor distribution and stage (invasion and atypia).

TABLE 2 - Tumor multiplicity, distribution and stage in each group.

\begin{tabular}{cccccccccc}
\hline Group & NRC & $\begin{array}{c}\text { Multiplicity } \\
\text { NCP } \\
\text { Median and } \\
\text { (min-max) }\end{array}$ & NCG & & SM & MUS & S/P/M & $\begin{array}{c}\text { Low } \\
\text { grade }\end{array}$ & $\begin{array}{c}\text { High } \\
\text { grade }\end{array}$ \\
\hline I & 2 & $0(0-1)$ & 02 & $1(50.00)$ & $1(50.00)$ & $0(00,00)$ & $\begin{array}{c}1 \\
(50.00)\end{array}$ & $\begin{array}{c}(50.00) \\
1\end{array}$ \\
II & 2 & $0(0-2)$ & 03 & $2(66.66)$ & $1(33.33)$ & $0(00,00)$ & $\begin{array}{c}(33.33) \\
6\end{array}$ & $\begin{array}{c}(66.66) \\
20\end{array}$ \\
III & 11 & $1(0-5)$ & 26 & $13(50.00)$ & $6(23.07)$ & $7(26.92)$ & $\begin{array}{c}(23.07) \\
6\end{array}$ & $\begin{array}{c}(76.92) \\
11\end{array}$ \\
IV & 5 & $4(1-6)^{\mathrm{d}}$ & 17 & $5(29.41)$ & $1(05.88)$ & $11(64.70)$ & $\begin{array}{c}(35.29) \\
2\end{array}$ & $\begin{array}{c}(64.70) \\
0\end{array}$ \\
V & 1 & $0(0-2)$ & 02 & 2 & $(100.00)$ & $0(00,00)$ & $0(00,00)$ & $(100.00)$ & $(00,00)$ \\
VI & 8 & $1(0-4)$ & 14 & $9(64.28)^{\mathrm{c}}$ & $4(28.57)^{\mathrm{b}}$ & $1(7.14)$ & $\begin{array}{c}3 \\
11\end{array}$ \\
\hline
\end{tabular}

NRC - number of rats with carcinomas;

NCP- number of carcinomas per rat;

NCG - number of carcinomas per group (min-max) minimum and maximum values;

$\mathrm{SM}$ - submucosa; MUS - muscle; S/P/M - serosa/peritonium/metastasis

a different from Group VI: $P=0.039$ (chi-square). Proportion of tumors $\mathrm{S} / \mathrm{M} / \mathrm{P}$ greater than in Group VI.

${ }^{\mathrm{b}, \mathrm{c}}$ different from Group IV: $P=0.039$ (chi-square). Proportion of tumors SM and M greater than in Group IV.

d different from Group VI: $P=0.0267$ (Mann-Whitney U test). Multiplicity greater in Group IV than in GroupVI. 


\section{Discussion}

The lower incidence of carcinomas in animals treated chronically with propolis (administered prior to and concomitantly with carcinogen), Group I, in relation to the incidence of carcinomas in the control group which received only carcinogen (Group VI), suggests that propolis has a chemopreventive effect against bladder carcinogenesis, when administered prior to the administration of BBN and continuously.

The findings are similar to the reported reduction of the incidence of tumors in mice with induced carcinogenesis of the skin $^{9}$ and lung ${ }^{17}$, when treated with Brazilian propolis. However, in these studies, propolis was not given prior to carcinogen but only concomitantly.

Raw green propolis, in the present study, contained 13.60 $\mathrm{mg}$ artepillin $\mathrm{C}$ per gram of propolis, but only one derivative of artepillin $\mathrm{C}$ was identified in lyophilized propolis.

The alcoholic extract of green propolis containing artepillin $\mathrm{C}$ and synthetic artepillin $\mathrm{C}$ reduced lung carcinogenesis in mice ${ }^{8}$ This indicates that other compounds were responsible for the decrease in the incidence of carcinogenesis in Group I. Is this an antioxidant or immunomodulatory effect?

The product of lyophilized propolis in the present study was submitted to an antioxidant assay using the 1,1-diphenyl-2 picryl-hydrazyl (DPPH) radical scavenging method. At a concentration of $1000 \mathrm{ppm}$, propolis showed antioxidant activity close to that of the controls vitamin $\mathrm{C}$ and Trolox, a synthetic antioxidant similar to vitamin E. $p$-Coumaric acid was one of the compounds identified in lyophilized propolis. These findings corroborate other reports in which the presence of flavonoids and derivates of $p$-coumaric acid was correlated with a substantial antioxidant activity ${ }^{18}$.

The immunomodulatory action of propolis has been described in experimental studies, but their findings have been conflicting and the complexity of the chemical composition of the propolis can be a factor, potentiating or suppressing immunological events $^{19}$.

An immunomodulatory effect was evoked in mice injected subcutaneously with Brazilian propolis, where the growth of Ehrlich's tumor was reduced, but this response was not seen with oral administration. However, propolis administered orally in combination with 5-FU reduced the tumor with improvement in the cytopenia induced by the antimetabolite ${ }^{20}$.

The incidence of tumors in rats treated with propolis by the subcutaneous route in the present study did not differ significantly in relation to the respective control.
Propolis not only from Brazil but other countries is studied in parallel with compounds of pharmacological interest isolated from them, such as artepilin C, CAPPE (caffeic acid phenethyl ester), $p$-coumaric acid, caffeic acid, quercetin, chrysin and naringenin, showing reduction of tumors in animals and cytotoxic effects in cultured human tumor cells ${ }^{21-25}$.

When comparing the incidence of Group I with that of the group that received propolis for 40 weeks, without administration of propolis prior to the carcinogen (Group III), a lower incidence of carcinomas was observed; that is, there was also a better protection by propolis in the group that was previously treated with propolis. However, there was no difference between Group III and the control (Group VI).

The variables analyzed here, including incidence, histopathology, multiplicity, invasion and atypia, did not reveal the effectiveness of propolis in the significant reduction of carcinogenesis when used concomitantly with the carcinogen for two routes of administration. Was the method of extraction of WSDP ineffective for obtaining active compounds from propolis? Could $L$-lysine have contributed to these results? Or both?

With regard to multiplicity (number of carcinomas per bladder), animals of the group treated with $L$ - lysine (Group IV) showed greater multiplicity of tumors than those that were given only the carcinogen (Group VI). Furthermore, these animals (Group IV) showed more invasive tumors reaching the peritoneum and had peritoneal metastases in relation to the control group (Group VI). That is, the proportion of tumors with an invasion degree of peritoneum and peritoneal metastasis was higher in Group IV. On the other hand, tumors of Group VI were less invasive with an invasion degree in general of submucosa and muscle.

The tumors of the group treated with $L$-lysine (Group IV) were also more invasive than those of the group treated with propolis (Group III).

In a study conducted in parallel with the present study during the publication process, it was seen that $L$-lysine stimulated angiogenesis in group IV. Could this be an explanation of the greater invasion of vesical tumors in animals treated with $L$ Lysine?

With respect to the incidence of carcinomas in group IV, another findings calls attention: $100 \%$ of the animals that were given $L$-lysine after the carcinogen developed carcinomas. This effect of $L$-lysine can be serve as a good model for the study of bladder carcinogenesis once initiated.

The higher multiplicity of tumors and degree of tumor invasion in animals treated with $L$-lysine and carcinogen, when compared to the control group (Group VI), means that $L$-lysine acts 
as a stimulus in bladder carcinogenesis. Recalling that the group treated only with $L$-lysine did not show vesical lesions, $L$-lysine appears to be an amino acid promoter of bladder carcinogenesis in rats at the doses and time utilized in these experiments.

Thesefindings contradictearlierstudies of theinvestigation of the promotion of carcinogenesis of the bladder in vitro. Kakizoe et $a l .{ }^{26}$ utilized bladder cells from rats treated with carcinogens and showed an increase in agglutination with concanavalin A, in the presence of a promoter of bladder carcinogenesis. This assay was then used to evaluate 21 amino acids ${ }^{27}$. Only $L$-isoleucine, $L$-leucine, $L$-valine and $D L$ - tryptophan showed statistically significant agglutination. $L$-Lysine agglutinated few initiated cells. In vivo studies confirmed these results, with respect to $L$-leucine, $L$-isoleucine and $D L$-tryptophan ${ }^{28,29,14}$. We did not find any reports that $L$-lysine is a promoter of bladder carcinogenesis.

Parallel assays, an unpublished unpublished results, were carried out with aorta blood (leukocytes - comet test) and femur bone marrow aspirate (micronucleus test), obtained at the time of euthanasia, to assess chronic genotoxity of propolis and $L$ -lysine and protection against the genotoxity of BBN by propolis and $L$ - lysine in all the animals of all groups. In the comet assay, the damage index in leukocytes showed that the rats of groups $\mathrm{V}$ and VI (animals that received BBN and water) were statistically higher $(\mathrm{p}<0.001)$ in relation to the groups I, II, III, IV, VII, VIII and IX, and that the animals of groups I and IV had a damage index lower than that of group I. On the other hand, a greater number of micronuclei were found in the bone marrow of rats of groups $\mathrm{V}$ and VI (animals that received BBN and water) in relation to the groups I, II, III, IV, VII, VIII and IX $(p<0.001)$. These results showed that both propolis and $L$-lysine at doses of $150 \mathrm{mg} / \mathrm{kg}$ body weight, for 40 weeks, are not genotoxic to bone marrow or peripheral blood leukocytes. Rather, the results suggest that propolis as well as $L$-lysine is efficient in protecting against genotoxicity in bone marrow and peripheral blood leukocytes, when comparing all the groups treated with carcinogens to the control groups V and VI, which received BBN and water oral and subcutaneous, respectively. These results contrasted with those of other investigators ${ }^{30}$, who identified acute mutagenic potential in vivo for Brazilian green propolis. However, it is necessary to point out that we used a much lower dose of propolis than that utilized in the cited study, and that the lack of artepillin $\mathrm{C}$ could have also had an influence. Therefore, we believe that it is essential to know the ranges of the genotoxic dose and chemoproventive dose for the safe use of propolis. Our study shows that the chronic use of propolis at low concentrations in rats is not genotoxic and is capable of protecting against the genotoxicity of BBN.
With respect to $L$ - lysine, although it has a promoter action (not genotoxic) in bladder carcinogenesis, it is also not genotoxic to bone marrow or peripheral blood leukocytes at the doses tested in the animals.

\section{Conclusions}

The green propolis (WSDP) has chemopreventive activity against carcinogenesis of the bladder in rats when administered prior to the carcinogen and continuously and that $L$-lysine promotes carcinogenesis of the bladder induced by BBN.

\section{References}

1. Fukushima S, Wanibuchi H. Prevention of urinary bladder cancer: the interface between experimental and human studies. Asian Pac J Cancer Prev. 2000;1:15-33.

2. Golijanin DJ, Kakiashvili D, Madeb RR, Messing EM, Lerner SP. Chemoprevention of bladder cancer. World J Urol. 2006;24:445-72.

3. Nacional Cancer Intitute. Estimated new cases and deaths from bladder cancer in the United States in $2011 \mathrm{http}: / /$ www.cancer.gov/ cancertopics/types/bladder of subordinate document. Accessed jul 31,2011

4. Kunze E, Chowaniec J. Tumor of the urinary bladder. Pathology of tumors in laboratory animals Lyon: IARC Sci Publ; 2001.

5. Mohr U. International classification of rodent tumours. Part I. The rat. 3-urinary system. Lyon: IARC Sci Publ; 1992.

6. Aga H, Shibuya T, Sugimoto T, Kurimoto M, Nakajima S. Isolation and identification of antimicrobial compounds in Brazilian propolis. Biosci Biotech Biochem. 1994;58(5):945-6.

7. Castro ML, Cury JA, Rosalen PL, Alencar SM, Ikegaki M, Duarte S, Koo H. Própolis do sudeste e nordeste do Brasil: influência da sazonalidade na atividade antibacteriana e composição fenólica. Quimica Nova. 2007;30:1512-6.

8. Kimoto T, Miyata SK, Hino K, Micallef MJ, Anaya T, Arai S, Ikeda M, Kurimoto M. Pulmonary carcinogenesis induced by ferric nitrilotriacetate in mice and protection from it by Brazilian propolis and artepillin C. Virchows Arch. 1990;438:259-70.

9. Mitamura T, Matsuno T, Sakamoto S, Maemura S, Kudo H, Suzuki S, Kuwa K, Yoshimura S, Sassa S, Nakayama T. Effect of a new clerodane dipertenoid isolated from propolis on chemical induced skin tumors in mice. Anticancer Res. 1996;16:2669-72.

10. Búfalo MC, Candeias JMG, Sforcin M. In vitro cytotoxic effect of brazilian green propolis on human laryngeal epidermoid carcinoma (HEp-2) cells. e-CAM. Doi: 10.1093/ecam/nem147. 2007.

11. Nicolov N, Marekov N, Bancova V, Popov S, Ignatova R, Valdimirova, I. Method for the preparation of water-soluble derivative of propolis. Patente no. 79903. 1987; Sofia. Bulgaria.

12. Nishio Y, Kakizoe T, Ohtani SS, Sugimura T, Fukushima S. L-isoleucine and L- leucine: tumor promoter of bladder cancer in rats. Science. 1986;231:843-5.

13. Ito N, Fukushima S. Promotion of urinary bladder carcinogenesis in experimental animals. Exp Pathol. 1989;36:1-15.

14. Oliveira PA, Colaço A, De La Cruz PLF, Lopes C. Experimental bladder carcinogenesis-rodent models. Exp Oncol. 2006;28:2-11.

15. Montesano R, Bartsch H, Boyland E, Della Porta G, Fishbein L Griesemer RA, Swan A B, Tomatis L, Davis W. Handling chemical carcinogens in the laboratory problems of safety. Lyon: IARC Sci Publ; 1979. 
16. Castegnaro M, Eisenbrand G, Ellen G, Keefer L, Klein D, Sansone EB, Spincer D, Telling G, Webb K. Laboratory decontamination and destruction of carcinogens in laboratory waste: some Nnitrosamines. Lyon: IARC Sci Publ; 1982.

17. Sugimoto Y, Iba Y, Kayasuga R, Kirino Y, Nishiga M, Hossen MA, Okihara K, Sugimoto H, Yamada H, Kamei C. Inhibitory effects of propolis granular A.P.C on 4-(methylnitrosamino)-1-(3-pyridyl)1-butanone-induced lung tumorigenesis in $\mathrm{A} / \mathrm{J}$ mice. Cancer Lett. 2003;193:155-9.

18. Simões LMC, Gregório LE, Da Silva Filho AA, Souza ML, Azzolini AECS, Bastos JK, Lucisano-Valim YM Effect of Brazilian green propolis on the production of reactive oxygen species by stimulated neutrophils. J Ethnopharmacol. 2004;94:59-65.

19. Ficher G, Hubner SO, Vargas GD, Vidor T. Imunomodulação pela própolis. Arq Inst Biol. 2008;75(2):247-53.

20. Suzuki I, Hayashi I, Takaki T, Groveman DS. Antitumor and anticytopenic effects of aqueous extracts of propolis in combination with chemotherapeutic agents. Cancer Biother Radiopharm. 2002;17(5):553-62.

21. Orsolic N, Knezevic AH, Sver L, Terzic S, Basic I. Immunomodulatoryy and antimetastatic action of propolis and related polyphenolic compounds. J Ethnopharmacol. 2004;94:30715.

22. Orsolic N, Kosalek I, Basic I. Synergistic antitumor effect of polyphenolic components of water soluble derivative of propolis against Ehrlich ascites tumour. Biol Pharm Bull. 2005;28(4):694700 .

23. Orsolic N, Terzic S, Mihaljevic Z, Sver L, Basic, I. Effect of local administration of propolis and its polyphenolic compounds on tumor formation and growth. Biol Pharm Bull. 2005;28(10):1928-33.

24. Orsolic N, Basic I. Water-soluble derivative of propolis and its polyphenolic compounds enhance tumoricidal activity of macrophages. J Ethnopharmacol. 2005 102:37-45.

25. Orsolic N, Stajcar D, Basic I. Propolis and its flavonoid compounds cause cytotoxicity on human urinary bladder transitional cell carcinoma in primary culture. Periodicum Biologorum. 2009;111(1):113-21.

26. Kakizoe T, Komatsu H, Honama Y, Nujima T. Detection of amino acids as possible promoters of bladder cancer in rats by measuring their enhancement of agglutination of bladder cells by concanavalin A. Gann. 1982;73:870-3.

27. Awale S, LI F, Onozuka H, Esumi H, Tezuka Y, Kadota S. Constituents of Brazilian red propolis and their preferential cytotoxic activity against human pancreatic PANC-1 cancer cell line in nutrient-deprived condition. Bioorg Med Chem. 2008;16:181-9.

28. Cohen SM, Arai M, Jacobs, JB, Friedell GH. Promoting effect of saccharin and DL-tryptophan in urinary bladder carcinogenesis. Cancer Res. 1979;39:1207-17.

29. Fukushima S. Modification of tumor development in the urinary bladder. Prog Exp. Tumor Res. 1991;33:154-74.

30. Pereira AD, Andrade SF, Swerts, MSO, Maistro, EL. First in vivo evaluation of the mutagenic effect of Brazilian green propolis by comet assay and micronucleus test. Food Chem Toxicol. 2008;46:2580-4.

\section{Acknowledgments}

We would like to thank Professor Maria Cristina Marcucci (UNIBAN, Bandeirante University of Sao Paulo) for typifying and quantifying our propolis samples and Professor Francisco Hélio Rôla from the Department of Physiology and
Pharmacology at UFC Medical School for his helpful suggestions and critical comments.

\section{Correspondence:}

\section{Conceição Aparecida Dornela}

Departamento de Patologia e Medicina Legal, Faculdade de Medicina

Rua Monsenhor Furtado, s/n

Caixa Postal 3169

60.441-750 Fortaleza - CE Brasil

Tel.: (55 85)3366-8300 / 3366-8301

Fax: (55 85)3366-8201

eusoucondor@yahoo.com.br

Received: September 21, 2011

Review: November 23, 2011

Accepted: December 20, 2011

Conflict of interest: none

Financial source: none

${ }^{1}$ Research perfomed at Laboratory of Experimental Surgery and Postgraduate Program, Department of Surgery, Faculty of Medicine, Federal University of Ceara (UFC), Brazil. 